\title{
ANALYZING COVID-19 CHALLENGES IN BANGLADESH
}

\author{
Jayasree Nath \\ Department of Environmental Sciences \\ Jahangirnagar University \\ Savar, Dhaka, Bangladesh \\ jayasreejaya10@gmail.com
}

\author{
Abdullah Fahim Chowdhury \\ Department of Environmental Sciences \\ Jahangirnagar University \\ Savar, Dhaka, Bangladesh \\ fahimpriom09@gmail.com
}

\author{
Amit Kumar Nath \\ Department of Computer Science \\ Florida State University \\ Tallahassee, Florida, United States \\ amitnath1614@gmail.com
}

\begin{abstract}
The effect of the COVID-19 pandemic in a developing country like Bangladesh is enormous. A research conducted by South Asian network of Economic Modelling predicted that the pandemic could double the poverty. But it is not that only the socioeconomic condition is dropping in Bangladesh, the impact of COVID-19 is manifold. The poor condition of Bangladesh's health sector has also been exposed due to the pandemic. People are not getting proper treatment due to lack of isolation beds, oxygen, ICU etc. The health sector of Bangladesh is not much developed and now with this pandemic it has become impossible to provide treatment facility for all the patients. Education sector, which is the backbone of a country, has also been greatly affected by the pandemic. We know that different types of cultural occasions are an inherited tradition of Bangladesh, COVID-19 have not spared even these traditions, all the cultural programs and festivals have been cancelled due to this pandemic. In this paper, our aim is to present the present status of all these sectors.
\end{abstract}

Keywords COVID-19 $\cdot$ Pandemic $\cdot$ Impact $\cdot$ Bangladesh

\section{Introduction}

World Health Organization (WHO) confirmed that the current outbreak of COVID-19 was first reported from Wuhan, China, on December 31, 2019. Considering the severity and fast spread of COVID-19, WHO had announced a global emergency on January 30, 2020, and officially called the outbreak as pandemic on March 11, 2020 [1]. Bangladesh can be identified as a highly spreading zone like any other effected countries. Though in many countries the virus started to affect people much earlier, in Bangladesh the 1st corona patient was detected in March 2020. Initially the spread of this pandemic was not so high but gradually the number of affected patients has increased and now in the middle of the June the number has risen near to 1 lakh people. This infection does not depend on the age of people. Though it is observed that elderly people remain at the highest risk of dying, people from all age groups are presently at danger [2]. In the developed countries the rate of older people getting affected is much higher than the younger people [3], But in Bangladesh quite a different scenario has been observed. In this developing country, people under age 50 are getting more affected [4]. From the reports it can be observed that $28 \%$ cases are of the age group 28 to 30 and $27 \%$ cases are of age 31 to 40. It even does not spare the little children. 3\% are already affected in the age group of 1 to 10 [5]. Because no vaccines or antiviral drugs have been discovered yet for the disease, many developed countries are using different types of interventions that are non medical to minimize the extension of the virus. Bangladesh is also trying to follow these interventions though one of the major interventions - mandatory lock-down cannot be followed properly in Bangladesh for the poor standard of life and dense population. Due to being a developing country, maximum citizen of 
A PREPRINT - JULY 16, 2020

Bangladesh live below the poverty line and they depend on day to day earning and they depend on day to day earning. Yet the interventions like social distancing, remote office activities, banning of international flights, banning inter district transportation are being followed to some extent [6]. But any interventions regarding COVID-19 spreading is affecting other sectors. The economic sector and the education sector are greatly affected since the start of COVID-19. The poor status of our health sector has come in front of everyone due to the pandemic. Some age-old cultural traditions stopped due to this pandemic. This research work will help us to know the challenges of COVID-19 on different crucial sectors in Bangladesh. The key sectors which we are focusing on are as follows - Economy, Education, Health, and Culture.

\section{Materials and Methods}

It is quite difficult to find updated and decisive information as the outbreak is still going on. In this paper a comprehensive study on the observed impact of the outbreak of COVID-19 on different sectors of Bangladesh is described. This study is based on secondary information. The information has been collected from the very beginning of the March 2020 to the middle of June 2020 and for this purpose we followed authentic newspapers, articles, media outlets and different research papers on this pandemic.

\section{Impact of Covid-19 on Different Sectors}

\subsection{Impact on Economy}

All around the world, even in the most developed countries, the COVID-19 pandemic has an extreme economic impact. So, it is obvious that for the developing nations the pandemic is causing a devastating effect [7]. As the COVID-19 cases are increasing every day, Bangladesh is being forced to endure lock-downs for different times and phases. These lock-downs are having a disastrous effect on workers and businesses across the country. The economy is now at halt. The effects of this are being observed in almost all sectors [8]. The earlier outbreak of COVID-19 in different countries forced Bangladeshi expatriates working in several countries of Middle East, Asia, Europe, Australia, and United States to return to their home to survive the impact of the disease along with their families. As a result. there is a significant disruption in the flow of remittance even after existing $2 \%$ stimuli offered from the government. Moreover, most of the countries where Bangladeshi workers were executing their jobs, are trying to control the continuous spread of COVID-19 by imposing partial or complete lock-down or travel restrictions that results in cascading the opportunities of both formal and informal jobs resulting from the shutdown of all economic activities [9]. The COVID-19 outbreak has already started to affect different sectors of economy. Among these, the three major sectors of the economy of Bangladesh that are Agriculture, Industry and Service sectors which generally contribute 18\%, 29\% and 53\% to the GDP of the country respectively, are adversely affected because of the coronavirus pandemic [10]. The overall impact of COVID-19 on these crucial economic sectors are described below -

\subsubsection{Industrial Sector}

Because of the worldwide pandemic people now realise that it would create an enormous threat for the garments industry which was responsible for the eighty percent of the country's exports which accounted $\$ 40$ billion in the last financial year. Many renowned industries had to face decisions such as cancellation and holding off their products which market price is nearly $\$ 3$ billion \& which would be a great loss during the global pandemic. COVID-19 would badly impact such as losing of the job on one million workers who are related with 450 spinning mills, 850 weaving mills and 250 dyeing factories [11]. Also, the COVID-19 pandemic has created disturbance in the supply chain. The drug manufacturers are now alarmed due to lack of pharma raw materials. According to the Bangladesh Association of Pharmaceutical Industry (BAPI), two-third pharmaceutical raw materials that are essential for manufacturing drugs are imported as illustrated on the chart in figure 1 .

\subsubsection{Agricultural Sector}

All the people of Bangladesh depend on agriculture either directly or indirectly. It is a major sector not only for our economy but also it is crucial for reducing our food insecurity. Nowadays, agriculture is not only confined to rice, vegetables, or fruits only, it also includes fisheries, poultry, livestock etc. Because Bangladesh did not experienced a phenomenon like COVID-19 in recent past, the situation is likely to directly affect the agricultural sector as well. Due to the COVID-19 pandemic the transportation of agricultural products like vegetables, grains, fruits, eggs, milk are stopped because of which farmers are deprived of the actual market price. Urban people are also deprived of fresh foods even at high prices [13]. Timing restrictions in the local markets have been imposed also. Social distancing is difficult to obey in these places. Within a fixed time, it becomes difficult for agricultural producers to sell their products 
A PREPRINT - JULY 16, 2020

nChaina India $\quad$ Korea $\quad$ Others $\quad$ Local Products

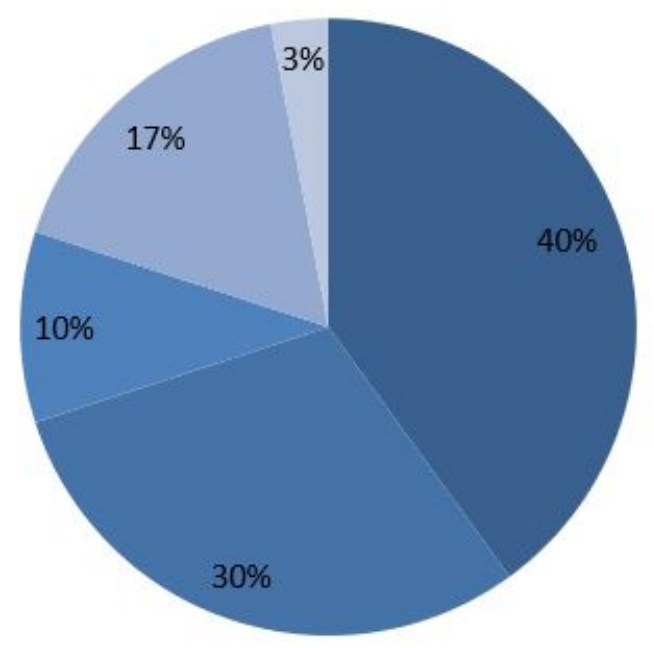

Figure 1: The source of pharmaceutical raw materials in percentage. [12]

in the markets. Most of the vegetables get rotten within a very short time,as a result it is impossible to store them which leaves farmers no way but to sell their product at a non profitable price. It is observed that cucumbers were sold at a price of Taka 3-5 per kg, eggplants were sold at Taka 5 per $\mathrm{kg}$ and tomatoes were sold at Taka 7-8 per $\mathrm{kg}$ which is $300 \%$ to $400 \%$ less than the normal price [14]. The lock-down had a severe impact on the fishermen also as they have not been able to sell their products in time. About $70 \%$ of the black shrimp are supplied to the European market $\&$ also local restaurant industry. This shrimp industry is facing losses as a result of this pandemic situation [15].

\subsubsection{Service Sector}

A huge number of people are going to be sacked from their jobs because of the long term lock down that is given as an order by the Government. Huge number of people are already without work which is claimed by several workers' rights organization and this number varies from 1.5 crore to upwards of 5 crores, while two economists said the number would be between 1.30 crore and 1.50 crore [16].

\subsubsection{Tourism Industries}

At least 12-15 international chain five-star hotels are situated in Bangladesh. Not only that, more than 600 three and two star unknown hotels and motels are located in all over the Bangladesh. This business helps many people to earn.The world will face a loss of USD 97.05 billion if this pandemic continues according to Pacific Asia Travel Association's Bangladesh chapter, till May 2020, in the tourism sector. Bangladesh is going to face an economic loss of more than Tk three billion. More than half a million of people, who are directly or indirectly employed in the tourism and hospitality industry, are going to face the risk of losing their jobs [17].

\subsection{Impact on Education}

Though the first corona patient was detected on March 8, the educational institutions remained open and the authority were not considering shutting down the educational institutions as an option. The primary and mass education ministry were considering adopting different ways \& habits in all primary schools regarding the do's and don'ts for students and teachers, which was for monitoring the situation according to the education ministry [18]. Awareness among different educational institutions continued through leaflets. The schools did not have enough sanitation facilities, adequate soap, or hand sanitizer. Many teachers and parents proposed to shut down the educational institutions due to lack of proper hygiene and the guidelines that are provided by the Government were quite impossible to follow [19]. Due to the increasing rates of Corona virus cases, students of 4 different departments of Dhaka University boycotted classes on March 15 [20]. Then finding no other way Education Minister Dr. Dipu Moni declared that all the academic institutions of the state will be obstructed till March 31, so that the spreading of deadly coronavirus can be minimized 
[21]. Despite the Governmental decision of closing of all the educational institutions, many coaching centers continued their operations [22].

On March 25, the Ministry of Education had extended the shutdown of all schools to April 9 from March 31 for the virus fears [23]. But as the days were proceedings the number of patients of COVID-19 were also increasing, as a result on April 7 the deputy education minister declared that holidays will be extended till the Eid holidays for all educational institutions [24]. On contemporary to cope with the pandemic situation, broadcast of secondary students classes started on March 29 and Government also started to broadcast the lessons for pre-primary students through "GHORE BOSE SHIKHI" (Learning while staying home) program so that the students can get educational facilities at large without getting effected [25, 26]. Because of the pandemic the University Grants Commission (UGC) told that they would give guidelines for the online classes of private universities \& with some conditions they have granted that private varsity would be able to take online classes since May 8 [27]. The S.S.C. \& equivalent exam result published on May 31 via text messages \& on website [28]. The H.S.C exam has also been postponed due to spreading of COVID-19 [29]. Recently the national budget have been announced but the educationalists think that with the allocation that is given in the educational sector it would not be possible to recover from the catastrophic situation as they predict that due to COVID-19 pandemic the rate of school dropout, the rate of early marriage will increase [30]. The COVID-19 cases are increasing exponentially in every day. Hence in this situation the Government has taken a decision that all the academic institutions will remain closed until there is no risk of spreading. Even if necessary, the educational institutions will remain closed till September 2020 [31].

Students are getting depressed day by day. The H.S.C. candidates do not have any clue of when their exams can be held. Frustration is growing around them. It is assumed that the session jam of the public university will increase at large if the situation remains same [32]. On the contrary, though the private universities are continuing their classes via online they are also facing many problems. In our country many students do not have internet facilities, so it is difficult for them to continue their classes through online. Also, according to students, it is difficult to learn through online classes. It is also difficult for the teachers to take class as they are used to take class through conventional methods [33]. This pandemic situation is not easy for anyone. The mental stress of the students is not less than any other. It is the time when the families should come forward to provide mental and moral support.

\subsection{Impact on Health}

Severe acute respiratory syndrome coronavirus 2 (SARS-CoV-2) is responsible for the ongoing pandemic which have not even spared Bangladesh [34]. Bangladesh declared the first confirmed case of coronavirus in the country after three people tested positive for the infectious virus in the capital Dhaka on March 8 [35]. The spreading of this pandemic remained in some sort of constant state till the end of March but just after entering into month of April a stiff increase in the case of effected people is noticed \& in June the increasing rate continued [36], (figure2) and same goes in the case of number of deaths, gradually the rate of death has also increased [36] as visible from figure 3.

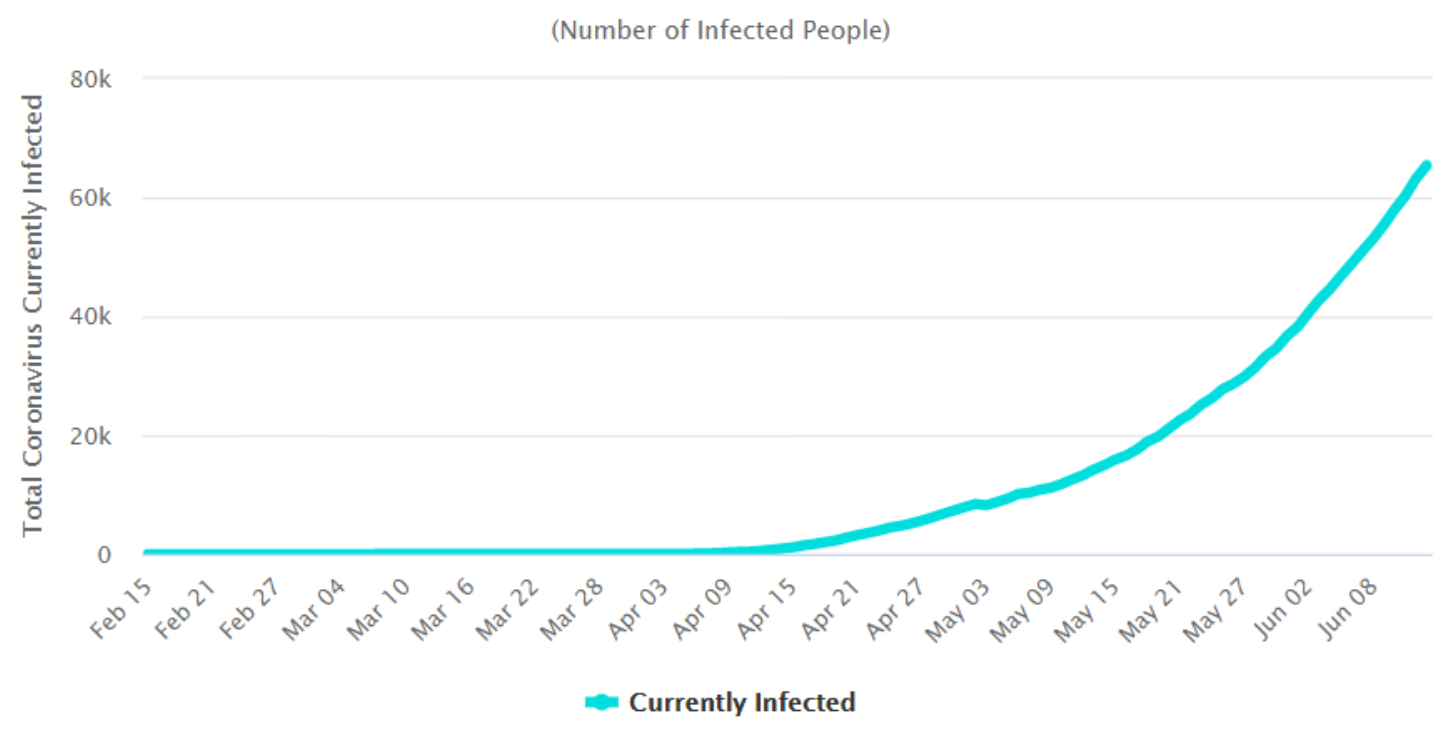

Figure 2: Total number of infected people till June 15. [36] 


\section{Total Deaths}

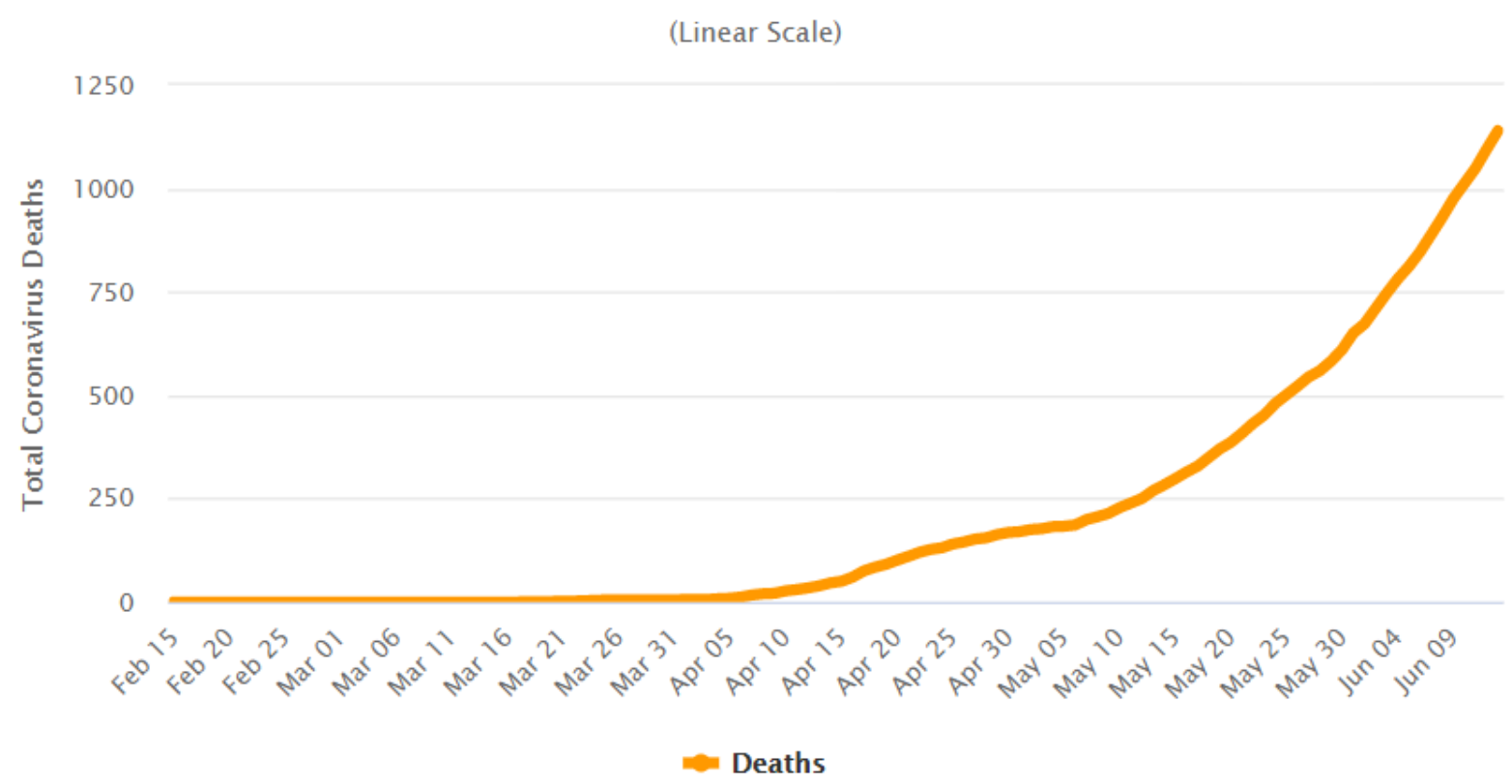

Figure 3: Total Number of Deaths till June 15. [36]

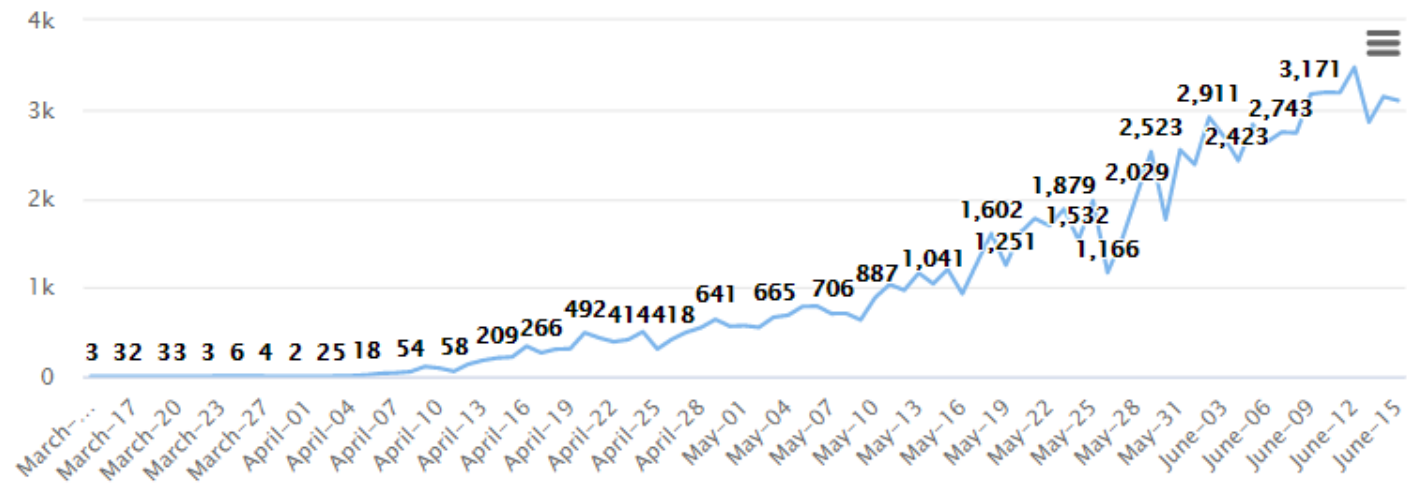

Figure 4: Total Number of affected people till June 15. [37] 


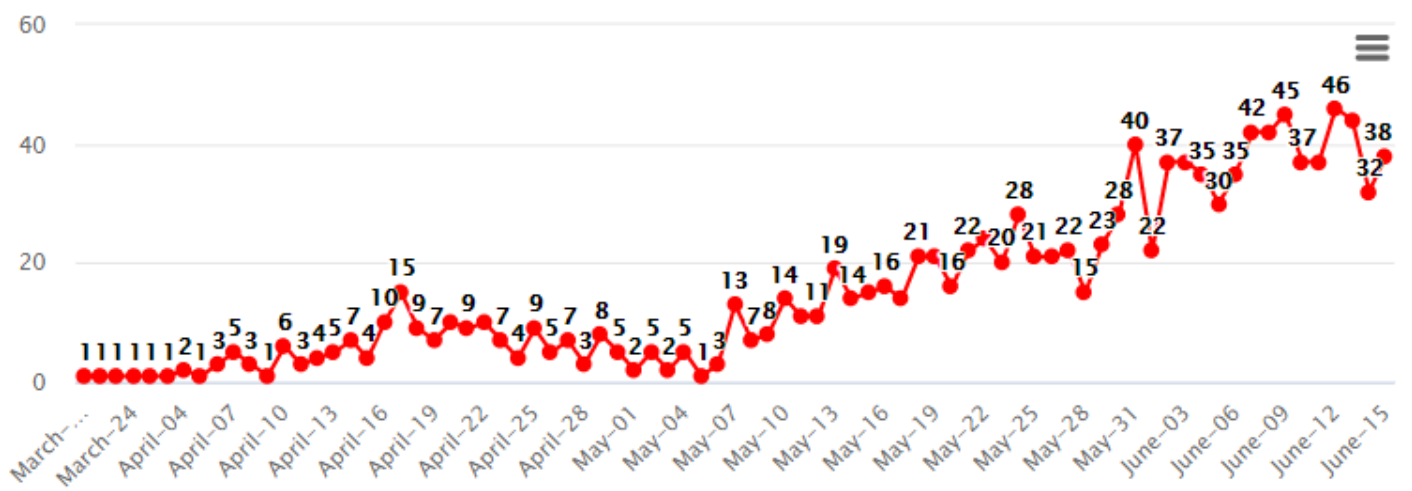

Figure 5: Total number of deaths till June 15. [37]

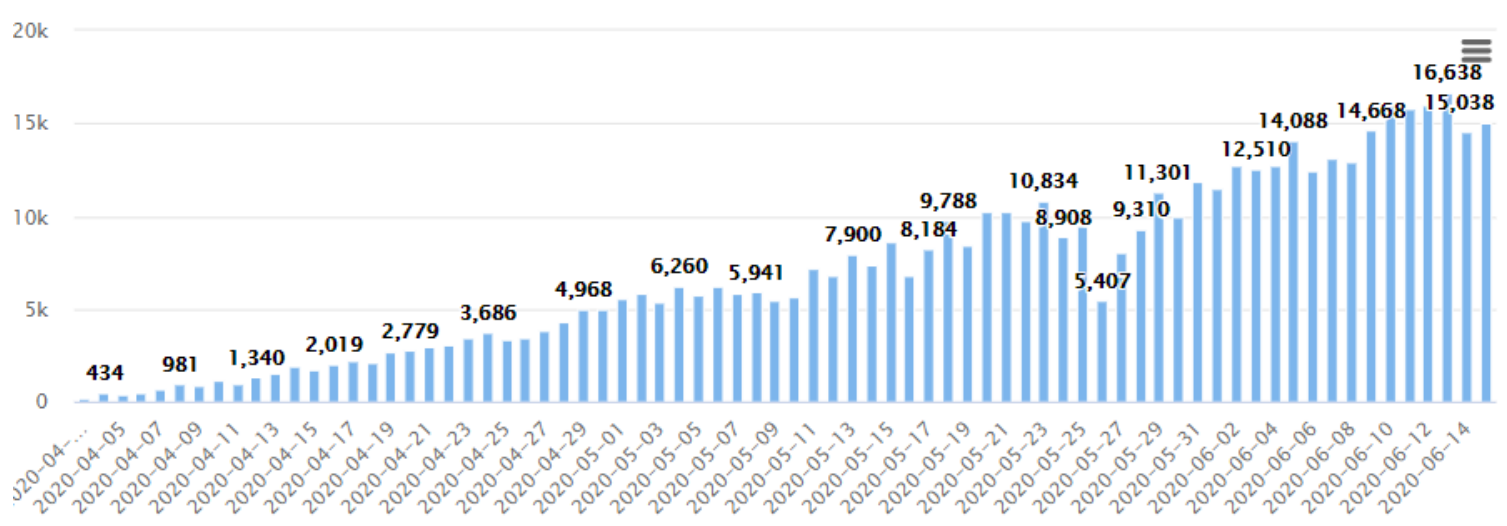

Figure 6: Total number of testing rates till June 15. [37]

At present (June 15) the number of patients has risen to 3000 [37] (figure 4) and the number of deaths has also increased over 40 [37], (figure 5).

The total number of Corona effected people till now (June 15) is 90,619 and total death due to corona is 1209 the case fatality rate is $1.3 \%$. However, this is not the actual scenario. Because the testing rate is very poor in Bangladesh [38] (figure 6).

The maximum testing rate is 16,638 person per day which is without any question very poor with respect of our population that is 161.4 million. Because of this the public health specialists think that this is not the actual scenario. Bangladesh do not have enough sufficiency for the treatment,isolation of the corona effected people. The reason behind this is the insubstantial public health services \& lack of the development of the public health sector. Overall there are only 127,000 hospital beds.Among these beds 91,000 of them are government-run hospitals. Apart from this, there are only 737 beds in intensive care units, with just 432 of these in the public health system.Another fact is that most of the healthcare facilities are capital centered. All the hospitals are overburdened now, these infrastructures will not be able to meet the challenges posed by COVID-19 [39].

However, now the Government have increased the number of hospitals from which people will be able to test COVID-19 and can have treatment facilities. The hospitals are Bangabandhu Sheikh Mujib Medical University (BSMMU), Kuwait Bangladesh Friendship Government Hospital, Kurmitola General Hospital, National Chest Infectious Diseases Hospital, Dhaka Medical College Hospital, Bangladesh Railway Hospital, Mohanagar General Hospital, Sheikh Russel Gastro Liver Institute \& Hospital, Sajida Foundation Hospital, Mirpur Maternity Hospital, Jinjira Specialized Hospital, Amin Bazar Hospital, Kamrangirchar Hospital [40], not only this but also different private hospitals such as Apollo Hospitals, Square Hospitals and United Hospital are declared to use for COVID-19 test [40]. Gradually some hospitals outside the capital are also facilitated with COVID-19 testing capacity but it is not sufficient. The doctors of these hospitals are getting effected due to corona virus enormously, nearly 1200 doctors are already affected due to corona virus [41] and each day doctors are dying. The main reason behind this is lack of protective gear, discrimination in the distribution of 
PPE, protective masks [42]. Also, during this pandemic people are not only dying by getting effected by corona virus but also many people are suiciding due to frustration, mental stress, being not able to pay the debts [43]. One of the major problem due to corona virus is that patients with other diseases are not getting treatment $\&$ this is getting worse day by day [44].

Again, there lies another health concern in the Rohingya camp. More than 1.1 million people are superseded by Myanmar \& they have started to live in rufuge camp in the Cox's Bazar district of Bangladesh. The Rohingya people are mostly at risk from the COVID-19 pandemic. It is quite difficult to follow the interventions such as Social distancing, case isolation that are required to halt the ongoing spreading of COVID-19 in this camp[45]. Till now thirty confirmed COVID-19 cases in the camps are detected, of 996 cases in the District were identified. Thirty six Rohingya refugees are sentenced to be in quarantine who had been in contact with a COVID-19 suspect or confirmed case, and 1,541 host community individuals in quarantine. 23 Rohingya refugees were kept in isolation who were suspected or confirmed cases of COVID-19, and 686 host community individuals in isolation [46]

Testing facility for the COVID-19 pandemic were set up in Cox's Bazar at the beginning of April and after testing on May 15, 145 Rohingyas had been tested. Among the preparedness actions to combat the pandemic one of them is the construction of new Severe Acute Respiratory Infection Isolation and Treatment Centers (SARI ITCs) which are expected to be ready within a very short time, that will treat Bangladeshis and Rohingya refugees requiring medical care for COVID-19 related illness [47].

One of the major initiatives that the Government has taken is that in the fiscal budget 2020-2021 the budget for health sector is Tk 29,247 crore for the health services and health education which is hiked by 23.44 percent from the revised budget of Tk 23,692 crore for the fiscal year 2019-20. According to the Finance Minister the allocation has been increased, keeping in mind that part of the fund will be spent on dealing with the pandemic [48].

\section{Impact on Culture and Entertainment}

Bangladesh is the ground of traditional rituals. But because of this pandemic the Bengali New Year celebration has been canceled which is organized by various cultural organizations. In addition to this, Mars Procession, Boishakhi Fair, Concert have been declared cancelled. [49]. Because of the virus whole wedding industry already suffered a great loss and now near to collapse [50].

Eid-ul-Fitr is being celebrated without any outdoor program. No Eid jamaat (congregation) was held at the National Eidgah Maidan this year due to the Covid-19 pandemic [51]. The State Minister for Youth and Sports has canceled all the National \& International upcoming scheduled events amid the COVID-19 pandemic [52].

Cinemas and television programs are very popular cultural sources of entertainment for the people of Bangladesh. Due to the pandemic, similar to the whole world, cinema halls and multiplexes have been shut down in Bangladesh since 18 March [53]. Running movie shoots have been postponed due to the lock-down. Similar thing happened for the television dramas, although news and talk show programs are still going on using virtual conferences and other measures.

Sports activities have also been postponed due to the pandemic. The Ministry of Youth and Sports postponed all kinds of matches (both domestic and international) [54]. As a result all ongoing and upcoming tournaments and tours have also been delayed.

\section{Discussion}

Like the rest of the world, the overall system in Bangladesh have collapsed to some extent due to the COVID-19 pandemic. As a result of the lock-down, the economic system has suffered tremendously. Some Financial packages from government is announced to help to mitigate this COVID-19 pandemic damage, in the national budget that is announced in COVID-19the midst of this pandemic, the GDP level of $8.2 \%$ has raised in the light of hope. The pandemic is having a huge impact on the students' education. It is not possible to take any classes and exams as the schools and colleges are closed. Although it is possible to alleviate this situation through online classes, it is not entirely possible. During the time of COVID-19, the health system of Bangladesh is facing a horrific situation. With the lack of protective equipment, it is difficult to deal with the situation. The world's largest refugee center is not outside the health risk of the world pandemic time. The lock-down also has affected the heritage and culture of Bangladesh. From the above discussion, we can predict about the Corona period in Bangladesh and we can also acknowledge that all the sectors are vulnerable during this pandemic specially for a developing country like Bangladesh. 
A PREPRINT - JULY 16, 2020

\section{Mitigation Measures}

It seems that the case of corona virus is not going to slow down. The most effective measure to stop spreading would be complete lock down of the country though it is not possible to continue for more than a month in the question of "Jibon Na Jibika". At least the most affected areas are needed full lock-down. For more, awareness should be made through different media. Government should strictly restrict the gathering of people \& should make it mandatory to keep 1 to 3 feet distance in a public place.

\section{Conclusion}

COVID-19 has proved to be a significant threat to the growth in different sectors in Bangladesh. Since we still do not have a clear idea about when the impact of COVID-19 would be reduced, we must cope up and adjust our lifestyle and working procedures accordingly. If we can adapt ourselves with this new normal, we would be able to sustain at least a modest level of growth in all sectors.

\section{Author Contributions}

JN: Conceived the idea, collected all information, and wrote the main manuscript; AFC: Analyzed data and edited the manuscript; AKN: Critically edited and revised the manuscript.

\section{Acknowledgement}

We are thankful to Dr. Mohammad Amir Hossain Bhuiyan, Professor, Department of Environmental Sciences, Jahangirnagar University for his precious time to review our literature and thoughtful suggestions.

\section{References}

[1] Ahmed Hossain, Juwel Rana, Md. Shadly Arefin, and Gias Ahsan. Report i: Weekly situation analysis of covid-19 in bangladesh. 032020.

[2] Coronavirus: $\quad 70 \%$ infected in Bangladesh aged 21 to 50 years (2020). https://www.dhakatribune.com/bangladesh/2020/04/03/coronavirus-73-infected-in-bangladesh-aged-21to-50-years.

[3] Basu, P. L. Age composition of population and Covid-19. https://www.wider.unu.edu/publication/age-compositionpopulation-and-covid-19.

[4] The Business Standard. 68\% of Covid-19 patients age 50 or below. https://tbsnews.net/coronavirus-chronicle/covid19-bangladesh/68-covid-19-patients-age-50-or-below-72247.

[5] Institute Epidemiology DC and R. COVID-19. (2020). https://www.iedcr.gov.bd/index.php/component/content/article/73ncov-2019.

[6] Nasrullah M Anwar S and Hosen MJ. Covid-19 and bangladesh: Challenges and how to address them. front. public health 8:154. 2020.

[7] World Economic Forum No refuge: the impact of coronavirus on the world's most vulnerable. https://www.weforum.org/agenda/2020/04/covid-19-coronavirus-vulnerable-refugees/.

[8] Global Times. Economic ramifications of Covid-19 in Bangladesh. https://www.globaltimes.cn/content/1187977.shtml.

[9] RM Lalon. Covid-19 vs. bangladesh: Is it possible to recover the impending economic distress amid this pandemic?

[10] M.S.; Barua S.; Alam M.J. Begum, M.; Farid. Covid-19 and bangladesh: Socio-economic analysis towards the future correspondence. 2020.

[11] The Business Standard. Pandemic hits hard all business sectors of Bangladesh. https://tbsnews.net/coronaviruschronicle/covid-19-bangladesh/pandemic-hits-hard-all-business-sectors-63517.

[12] The Business Standard. Pharma industry braces for raw material crisis. https://tbsnews.net/companies/pharma/pharma-industry-braces-raw-material-crisis-54640. 
A PREPRINT - JULY 16, 2020

[13] Ali, MS. Addressing the effects of COVID-19 on Bangladesh agriculture. https://greenwatchbd.com/addressingthe-effects-of-covid-19-on-bangladesh-agriculture/.

[14] Ubinig.Covid-19 Bangladesh: UBINIG REPORT SERIES 1: Farming community Agriculture. http://ubinig.org/index.php/home/showAerticle/218/english/UBINIG/Covid-19-Bangladesh:-UBINIGREPORT-SERIES-1:-FARMING-COMMUNITY--AGRICULTURE.

[15] The Fish Tank. Fish and Aquatic Food Systems COVID-19 Updates: Bangladesh. http://blog.worldfishcenter.org/2020/05/covid-19-updates-bangladesh/.

[16] The Daily Star. More than a crore with no job and hope. https://www.thedailystar.net/business/news/more-croreno-job-and-hope-189855.

[17] New Age Youth. The impact of COVID-19 in tourism and hospitality industry of Bangladesh. https://www.newagebd.net/article/106347/the-impact-of-covid-19-in-tourism-and-hospitality-industry-ofbangladesh.

[18] The Daily Star. Educational Institutions: Shutdown not in consideration yet. https://www.thedailystar.net/frontpage/news/educational-institutions-shutdown-not-consideration-yet-1878151.

[19] The Daily Star. Coronavirus Prevention: How prepared are schools? https://www.thedailystar.net/frontpage/news/coronavirus-prevention-how-prepared-are-schools-1879912.

[20] Daily Bangladesh.4 DU departments announce boycott over coronavirus panic. . https://www.dailybangladesh.com/english/4-DU-departments-announce\%C2\%A0boycott-over-coronavirus-panic/38694.

[21] United News of Bangladesh. All educational institutions to remain closed till March 31: Dipu Moni. https://unb.com.bd/category./Bangladesh/coronavirus-bangladesh-shuts-down-educational-institutions/47157.

[22] The Daily Star. Coaching centres open, defying govt directive. https://www.thedailystar.net/city/news/coachingcentres-open-defying-govt-directive-1882801.

[23] bdnews24.com. Bangladesh Govt extends shutdown of schools to Apr 9. https://bdnews24.com/bangladesh/2020/03/24/govt-extends-shutdown-of-schools-to-apr-9.

[24] Dhaka Tribune. Coronavirus: Educational institutions to remain closed till Eid holidays. https://www.dhakatribune.com/bangladesh/2020/04/07/coronavirus-educational-institutions-to-remain-closedtill-eid-holidays.

[25] The Daily Star. Primary students' TV classes go on air Thursday. . https://www.thedailystar.net/city/n.ews/primarystudents-tv-classes-go-air-thursday-1889911.

[26] The Financial Express. Primary school students to get televised lessons from Tuesday. https://thefinancialexpress.com.bd/education/primary-school-students-to-get-televised-lessons-from-tuesday1586091940.

[27] The Business Standard. Private university students taking online classes. https://tbsnews.net/coronaviruschronicle/covid-19-bangladesh/private-university-students-taking-online-classes-64867.

[28] Dhaka Tribune.1,35,898 students get GPA 5 in SSC exams. https://www.dhakatribune.com/bangladesh/education/2020/05/31/135-898-students-get-gpa-5-in-ssc-exams.

[29] The Daily Star. Coronavirus: HSC, equivalent exams postponed. https://www.thedailystar.net/hsc-exam-2020postponed-due-to-coronavirus-fears-in-bangladesh-1884304.

[30] The Daily star. Budget for coronavirus-battered education sector unchanged. https://www.thedailystar.net/bangladesh-budget-2020-21-for-education-sector-unchanged-1912649.

[31] The Business Standard. Educational institutions may remain closed till September if virus does not fade:PM. https://tbsnews.net/bangladesh/education/all-educational-institutions-remain-closed-till-september-pm-74221.

[32] The Daily Star. Public Universities: Session jams loom large . https://www.thedailystar.net/frontpage/news/publicuniversities-session-jams-loom-large- 1895887.

[33] Islam, S. Online education and reality in Bangladesh. . https://www.observerbd.com/details.php?id=256102.

[34] MSD Manual Professionals Version: Coronaviruses and Acute Respiratory Syndromes (COVID-19, MERS, and SARS. . https://www.msdmanuals.com/professional/infectious-diseases/respiratory-viruses/coronaviruses-andacute-respiratory-syndromes-covid-19,-mers,-and-sars.

[35] Sakib, Nazmus SM. Bangladesh confirms first case of coronavirus. https://www.aa.com.tr/en/asiapacific/bangladesh-confirms-first-case-of-coronavirus-/1758924.

[36] Worldometer. Covid-19 Coronavirus Pandemic (2020). . https://www.worldometers.info/coronavirus/country/bangladesh/. 
[37] Coronavirus COVID-19 Dashboard, 2020. . http://103.247.238.92/webportal/pages/covid19.php.

[38] The Diplomat. The COVID-19 Catastrophe in Bangladesh. . https://thediplomat.com/2020/04/the-covid-19catastrophe-in-bangladesh/.

[39] Brac University. List of Hospitals. https://www.bracu.ac.bd/covid-19-bu-hotline-0155661013901893874121/updates-and-information/list-hospitals.

[40] NewAge Bnagladesh. Three private hospitals allowed to test COVID-19. . https://www.newagebd.net/article/105379/three-private-hospitals-allowed-to-test-covid-19.

[41] ArabNews. Bangladesh loses doctors to COVID-19. https://www.arabnews.com/node/1689996/world.

[42] The Business Standard. Doctors, nurses getting sick: Protective gear, curbs on non-essential services can save lives. https://tbsnews.net/coronavirus-chronicle/covid-19-bangladesh/doctors-nurses-getting-sick-protective-gearcurbs-non.

[43] N; Pakpour H A: Griffithis DM.; Mamun A M Bhuiyan, Israfil M.K.A.; Sakib. Covid-19-related suicides in bangladesh due to lockdown and economic factors: Case study, evidence from media report. 2020.

[44] UNDP Bangladesh.Covid-19: A reality check for Bangladesh's healthcare system. . https://www.bd.undp.org/content/bangladesh/en/home/stories/a-reality-check-for-bangladesh-s-healthcaresystem.html.

[45] MEDECINS SANS FRONTIERES. Five challenges for the Rohingya in Bangladesh amid COVID-19. COVID-19 and the Rohingya Refugees in Bangladesh: The Challenges and Recommendations.

[46] Inter Sector Coordination Group. https://www.humanitarianresponse.info/sites.

[47] United News of Bangladesh. Coronavirus test, treatment equally available to Rohingyas, locals: ISCG. https://unb.com.bd/category/Bangladesh/coronavirus-test-treatment-equally-available-to-rohingyas-localsiscg/51661.

[48] The Business Standard. Health sector gets priority in the budget for 2020-21. https://tbsnews.net/economy/budget/health-sector-gets-priority-budget-2020-21-91807.

[49] Union of Catholic Asian News. New Year spirit endures despite Bangladesh lockdown. https://www.iedcr.gov.bd/index.php/component/content/article/73-ncov-2019.

[50] The Business Standard. Marriage of an expat stopped in Dhaka over coronavirus. https://tbsnews.net/bangladesh/marriage-expat-stopped-dhaka-over-coronavirus-58339.

[51] Dhaka Tribune. Bangladesh celebrates Eid-ul-Fitr amid coronavirus pandemic. https://www.dhakatribunecom/bangladesh/2020/05/25/bangladesh-celebrates-eid-ul-fitr-amid-coronaviruspandemic.

[52] The Financial Express. Govt suspends all sporting events amid COVID-19 pandemic. . https://thefinancialexpress.com.bd/sports/govt-suspends-all-sporting-events-amid-covid-19-pandemic1584370944.

[53] Movie Making and Release Stopped due to Corona. https://www.bd-pratidin.com/entertainmentnews/2020/05/07/527713.

[54] Coronavirus brings Bangladesh's sports to a halt. https://tbsnews.net/sports/coronavirus-brings-bangladeshssports-halt-57490. 